\title{
UNIFORM APPLICATION OF THE INTERNATIONAL SALES LAW/UNDERSTANDING UNIFORMITY, THE GLOBAL JURISCONSULTORIUM AND EXAMINATION AND NOTIFICATION PROVISIONS OF THE CISG
}

\author{
Edited By Camilla B. Andersen, Kluwer Law International, The \\ Netherlands, 2007
}

\section{Reviewed by Melissa Ann Pansiri, Esquire*}

As a student at the University of Pittsburgh School of Law, my favorite courses were International Sales and International Business Transactions. The former I appreciated for nourishing my academic interest in the United Nations Convention on Contracts for the International Sale of Goods (CISG), while the latter I appreciated for instilling in me the tools to be a responsible transactions attorney. Learning from professors like Professor Harry Flechtner and Professor Ronald Brand, my profound interest in the CISG grew, and I realized a deep appreciation for scholarly commentary on the CISG. Herein, I discuss a book about the uniform application of the CISG, including obstacles to uniform application of the CISG.

As a student, I learned that a broad notion of uniformity underlies the core of the CISG. In this regard, this notion is evident in the Preamble, "uniform rules," and Article 7(1), "the need to promote uniformity in its application." While removing inconsistency, a barrier to international trade, is a good idea, we must determine "how [to] deal with uniform international law on a practical level once it has been created and applied to commercial law."1

In Dr. Camilla Baasch Andersen's book, Uniform Application of International Sales Law, she discusses two developments in international commercial law, namely the harmonization and unification of international

* JD, University of Pittsburgh School of Law, 2008. Admitted to the Bar of the Commonwealth of Pennsylvania. Participant, Willem C. Vis International Commercial Arbitration Moot, 2008. I want to thank Professor James Flannery for commenting on prior drafts of this review.

1. Albert H. Kritzer, Foreword to Camilla BaAsch Andersen, Uniform Application of the International Sales Law/Understanding Uniformity, the Global Jurisconsultorium and Examination and Notification Provisions of the CISG XIII (2007) [hereinafter Uniform Application of International Sales Law]. 
trade law through the CISG and how to deal with such uniform international law on a practical level. As she states, "the main theme of this book is to promote global use of cases and scholarship to help understand the uniformity of the CISG in its application." ${ }^{2}$ Dr. Andersen's book as a whole is important because a commercial law practitioner will have "a wider base of judgments to guide their application of the law," ${ }^{3}$ to aide in presenting their client's position and, hopefully, succeeding in an effort to persuade a tribunal that this position is the right position.

Dr. Andersen's book is organized in the following way. First, she describes the concepts of uniformity ${ }^{4}$ and the Jurisconsultorium. ${ }^{5}$ Second, she discusses the CISG and its place in terms of both concepts, especially uniformity in interpretation and application and the use of the Jurisconsultorium as a tool for uniform application. Third, Dr. Andersen points out general challenges to the uniformity of the CISG, and addresses and analyzes in more specificity one of the challenges to the uniform interpretation and application of the CISG, specifically challenges to the provisions ${ }^{6}$ dealing with examination and notification in cases concerning non-conforming goods. ${ }^{7}$ Fourth, she contributes her conclusions on uniformity of the CISG. ${ }^{8}$

The Uniform Application of International Sales Law enriches the CISG scholarly landscape by addressing the uniformity of application and interpretation of the CISG at a practical level. For example, Dr. Andersen addresses the challenges of uniform application and interpretation of the CISG in determining the timeframe for notification by the buyer to the seller of non-conformity of the goods. ${ }^{9}$ Dr. Andersen chooses the areas of examination

\section{Id. at 1 .}

3. $I d$.

4. Dr. Andersen posits that under the surface, uniformity in application of the CISG may be elusive. However, in attaining any similarity in result, it is "the way rules are applied" that is significant. Id. at 6.

5. The Jurisconsultorium is "a shared interpretational sphere or cross-jurisdictional 'common law,' which can 'evolv[e] an international scholarly consensus of interpretation,' or allow 'courts and tribunals to look directly to a consensus shaped in international case law."' $I$ d. at 13, 233.

6. CISG arts. 38, 39, 40, 44.

7. Dr. Andersen demonstrates, in Chapter V through VII, that the provisions on notification and examination regarding non-conforming goods, and their exceptions in CISG articles 38, 39, 40, and 44, are not uniformly applied and interpreted due to, inter alia, a lack of textual uniformity or domestic law being equated to uniform law. Uniform ApPLiCATION OF INTERNATIONAL SALES LAw, supra note 1, at 133-225.

8. The most significant of these conclusions are that the CISG "was diplomatically drafted to remove barriers of trade, but not to establish strict uniformity of law throughout its application"; the CISG "aims at the establishment of autonomous terminology"; and "the global jurisconsultorium is a significant tool in obtaining uniformity as it ensures that views and interpretations are shared." Id. at 229.

9. Id. at 139. See CISG art. 39 (defining when the buyer should notify the seller of any non-conformity of the goods or the timeframe for notification); UNIFORM APPLICATION OF INTERNATIONAL 
and notification when there are non-conforming goods to discuss and analyze because "there is a great deal of interpretational margins, and these provisions contain examples of several different questions of interpretation which have had different outcomes in international case law."

By choosing the areas of notification and examination and their exceptions to discuss and analyze, Dr. Andersen imparts her main theme-to promote global use of cases and scholarship to help understand the uniformity of the CISG in its application. In this regard, for example, Dr. Andersen discusses the challenges of uniformity of Article 39(1). ${ }^{11}$ These challenges include regionally evolved guidelines based on isolated scholarly opinions with regard to the determination of a reasonable time for notification, specifically German and Austrian guidelines, ${ }^{12}$ and the lack of textual uniformity regarding the specificity of notice, specifically the German translation of CISG Article 39(1) ("specify exactly") and the English text of CISG Article 39(1) ("specifying the nature"). ${ }^{13}$ The lesson learned when facing each of these challenges is that without the use of the global Jurisconsultorium, a tribunal would fall prey to these varying interpretations resulting in an outcome that varies from the trend and strays from uniform interpretation and application of a uniform law. ${ }^{14}$

Readers from all perspectives (whether a student, scholar, or practitioner) will enjoy Dr. Andersen's book. From a student's perspective, the methodical approach Dr. Andersen uses to explore the issues of uniform application of the CISG leads to a deeper understanding of the CISG. For the scholar, the problems Dr. Andersen raises regarding uniform application of the CISG pose an opportunity for further exploration. From these perspectives, chapter IV is academic scholarship that enriches the landscape of the CISG and fuels further discussion in hopes of gaining a resolution to the problems posed. In this regard, Dr. Andersen analyzes only on the surface the challenges of uniform

SALES LAW, supra note 1, at 149-62 (discussing Article 39 which defines when the buyer should notify the seller of any non-conformity of the goods or the timeframe for notification; Article 38 which defines when the buyer should examine goods or the timeframe for examination; the exceptions to the notification rule; and the use of the global Jurisconsultorium to determine any trends in uniform interpretation and application, and a lack thereof).

10. Uniform Application of International Sales Law, supra note 1, at 141.

11. CISG art. 39(1) provides that the buyer must notify the seller of a lack of conformity "within a reasonable time after he has discovered it or ought to have discovered it" or the buyer "loses the right to rely on a lack of conformity of the goods." Id. at 138. In other words, the buyer loses remedies or has remedies severely reduced if the buyer does not notify the seller of a non-conformity within in a reasonable time.

12. See Uniform Application of International Sales Law, supra note 1, at 182.

13. See id. at $189-90$.

14. Id. at $186-87,190$. 
application of the CISG in its terminology, scope of application, classification or characterization of the legal issues, and gap-filling. Her hope is that scholars will contribute or continue to contribute to the global Jurisconsultorium to "help establish autonomous interpretations where high levels of uniformity are possible." 15

For the practitioner, Dr. Andersen introduces and describes the global Jurisconsultorium, which can assist a practitioner and aide the lex fori or other adjudicatory body in understanding the various interpretations of certain articles of the CISG. From a practitioner's perspective, chapter III is the most useful because it lays out the tools available to transnational attorneys, including the Pace CISG database, which contains translations of case law from other countries interpreting the CISG. Dr. Andersen is correct in stating that "no transnational lawyer can adequately represent his or her client without making good use of it." 16

Dr. Andersen's book clearly demonstrates that the Jurisconsultorium is a necessary tool in uniform interpretation of the CISG as it allows views and interpretations of the CISG to be shared. Without these shared views, misinterpretation of the CISG will result. 